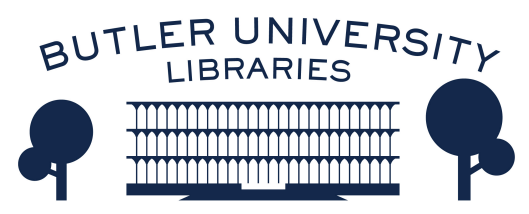

Journal of Hindu-Christian Studies

\title{
Book Review: Longing and Letting Go: Christian and Hindu Practices of Passionate Non-Attachment
}

Tracy Sayuki Tiemeier

Loyola Marymount University

Follow this and additional works at: https://digitalcommons.butler.edu/jhcs

Part of the Christianity Commons, Hindu Studies Commons, and the Religious Thought, Theology and Philosophy of Religion Commons

\section{Recommended Citation}

Tiemeier, Tracy Sayuki (2017) "Book Review: Longing and Letting Go: Christian and Hindu Practices of Passionate Non-Attachment," Journal of Hindu-Christian Studies: Vol. 30, Article 15.

Available at: https://doi.org/10.7825/2164-6279.1667

The Journal of Hindu-Christian Studies is a publication of the Society for Hindu-Christian Studies. The digital version is made available by Digital Commons @ Butler University. For questions about the Journal or the Society, please contact cbauman@butler.edu. For more information about Digital Commons @ Butler University, please contact digitalscholarship@butler.edu. 


\section{Longing and Letting Go: Christian and Hindu Practices of Passionate Non- Attachment. By Holly Hillgardner. New York: Oxford University Press, 2017, 174 pages.}

HOLLY Hillgardner has written a rare gem of a book. In it she brings together sixteenth century Vaishnava poet Mirabai and thirteenth century Christian Beguine Hadewijch in order to demonstrate how practices of passionate nonattachment reorder (and relate) the erotic with the ascetic and suggest an interreligious ethic for our day. The result is an important contribution to numerous disciplinary areas, including (but not limited to) feminist theology, comparative theology, Hindu-Christian studies, and comparative mysticism.

Hillgardner begins with an examination of Mirabai that emphasizes the category of viraha bhakti and the cultivation of separation between devotee and Krishna. Reading Mirabai through the lens of viraha bhakti leads Hillgardner to reflect on the significance of lovelonging and of Mirabai's holding together of the practices of longing and letting go. Hillgardner focuses on verses where Mirabai imagines herself as both a wife to Krishna and an ascetic yogini. The yogic marriage holds together passion and non-attachment in ebbs and flows, an oscillation that serves to highlight the middle spaces of love-longing and multiple totality of divine presence-in-absence. Mirabai's selfdepiction in some songs as a married yogini holds together passion and non-attachment. In imagining herself as both yogi and lover, Mirabai is able to use viraha bhakti as a liberating force. Hillgardner suggests that practices of passionate non-attachment can be liberating for women and other marginalized peoples.

Hillgardner's choice to use viraha bhakti as the primary hermeneutical lens for reading Mirabai is an attempt to avoid Western hegemonic categories and epistemologies. This is a fruitful strategy. Her chapters on Mirabai are excellent. But Hillgardner not only reads Mirabai through the lens of viraha bhakti, she also draws on viraha bhakti to read Hadewijch. This move further decenters Western hegemony. And it also makes for a unique and fascinating contribution to Hadewijch studies in its own right.

Hillgardner introduces Hadewijch with a helpful discussion of how Hadewijch combines Christian bridal mysticism and secular courtly love literature. This unique combination leads Hadewijch's writings to be particularly fluid and complex, with gender reversals for soul and God. That is, whereas medieval writers portrayed the soul as female and the divine as male (and so numerous male writers identified with the female bride/soul in relationship to the bridegroom/God), Hadewijch employed secular courtly love tropes to portray herself as a male knight in love with a female beloved. Where she does use bridal mysticism, she highlights erotic mutuality, female sexuality, and longing. In Chapter Five, Hillgardner focuses on Hadewijch's idea of "noble unfaith," which brings together loving and letting go. Noble unfaith is restless desire, a force that moves the soul into the abyss where God and soul meet. 
Love (Minne) cannot be fully known or possessed, and so noble unfaith leads the soul to grief and non-fruition. But because of the meeting of God and soul in the abyss, even though it must be a union with Love as "abyss of unknowing," it is also blissful and fecund. However, through the lens of viraha bhakti, Hillgardner suggests that this union in a bottomless pit is an erotic mysticism of separation, a mysticism that resides in the middles spaces of presence and absence, grief and joy, passion and non-attachment. The transformation through separation, mourning, and grief that is central to viraha bhakti is a way to understand the fecundity of Hadewijch's own practices of passionate non-attachment.

In the extended comparison of Chapter Six, Hillgardner flushes out the relationship between passion and non-attachment, longing and renunciation. Both Mirabai and Hadewijch hold together desire and non-attachment in their practices. Even so, there are important differences in their love-longing. If Hadewijch is more confident in the possibility of conquering love, Mirabai is more uncertain about Krishna's return. Noble unfaith is a choice for the few; the path of separation is not a choice for Mirabai. For Hadewijch, fear drives noble unfaith; for Mirabai, there is no fear (though there is deep grief). Ultimately, for Hadewijch, the overall mode of love-longing is an active passion that is directed to winning Love. For Mirabai, the overall mode is an active passivity that is focused on waiting. In this chapter, Hillgardner also draws out interesting similarities and differences in how Mirabai and Hadewijch approach communal love-longing, middles spaces of longing, and cultivated practices of attachment.
Hillgardner spends her final two chapters exploring the practical and ethical implications of passionate non-attachment. Chapter Seven seeks to develop an anthropology of constitutive relationality, an articulation of the essential ways love-longing widens the "I" to divine and human others. Hillgardner does this by drawing on feminist theorist Judith Butler's notion of "dispossession." For Butler, dispossession is actually an ecstatic movement that undoes the self and exposes the self in fundamental yet "unknowing" and mysterious relationship with the other. Hillgardner argues that, in their lovelonging, Mirabai and Hadewijch dispossess: undoing of self, other, and divine is not the goal but rather the result of deep, passionate attachments. Thus, the notion of dispossession highlights the fundamental relationship between desire and non-attachment as well as the fundamental and darkly mysterious relationship between self and other.

In light of the outward, ecstatic movement she draws out in her comparison between Mirabai and Hadewijch, Hillgardner ultimately proposes an interreligious lived ethic of passionate non-attachment. She considers several issues where practicing passionate nonattachment could be productive, including the environment, gender, interfaith relations and religious identity, and method in comparative theology. Indeed, Hillgardner does offer fascinating hints at the ethical implications of holding together passion and non-attachment, though her ideas here are more like initial reflections than a systematic presentation of what an interreligious lived ethic of passionate non-attachment really entails.

Hillgardner is to be commended for a remarkable contribution to Hindu-Christian studies (not to mention comparative theology, 
feminist theology, and the comparative study of mysticism). The volume is quite readable-without losing any scholarly facility. It may be beyond the reach of many undergraduate students, but the book will be immensely valuable to graduate students, scholars, and anyone interested in Mirabai, Hadewijch, and/or comparative studies.

Tracy Sayuki Tiemeier

Loyola Marymount University

\section{Abhishiktananda (Henri Le Saux): Christian Nondualism and Hindu Advaita. By J. Glenn Friesen. Calgary: Aevum Books, 2015, 592 pages.}

SWAMI Abhishiktananda (Henri Le Saux 19101973) was raised in a sheltered, religious family in France. Later, as a priest and monk, and inspired by missionary aims and the ideal of inculturation, he went to India to establish a Benedictine monastery. Wanting to establish an inculturated form of Christian monasticism, he keenly observed Hindu ways and culture. Through exposure to Ramana Maharishi, Abhishiktananda became convinced that a profound experience of God could be found in Advaita Vedanta. He spent the next two decades, until his death, immersing himself in Advaitic spirituality. Retaining his identity as a Catholic priest and monk throughout those decades, he attempted to relate his Catholic beliefs to his newer, Advaitic experiences. His published books appear to give clear-cut resolutions of the issues, but when one examines his letters and diaries, one sees that his books are snapshots of a turbulent flow, moments frozen in time.

Through a variety of books and articles published since the 1970s, Abhishiktananda's thought has been well marked out. Friesen's recent contribution is to lay out a wide variety of categories, and to examine Abhishiktananda's thought in these categories, paying attention to how his thought changed. These categories include "transcendence," "immanence," "non- duality," and "levels of perception." Significantly, he maps out the variety of positions that fall under each category. Friesen also includes Christian theological categories, such as "Christology" and "eschatology." Further, he brings Abhishiktananda's thought into dialogue with what some classic scholars of Eastern religions, such as Paul Hacker and David Loy, who have written about non-dual traditions. In addition, he identifies some of the many diverse influences on Abhishiktananda's thought.

Friesen makes many points in this lengthy study. His main point is to show how Abhishiktananda's thinking in the various categories mentioned above changed because of his exposure to Advaita. However, he concludes that Abhishiktananda's success in bridging Catholic belief with Advaitic experience is wanting. To begin, Abhishiktananda's thought was shifting and inconsistent. Further, it had a strong acosmic aspect. Friesen looks askance at acosmism, believing, although he points out that Abhishiktananda himself was not callous, that acosmism contributes to a callous disregard of the world's suffering.

Dissatisfied with Abhishiktananda's attempted resolutions, Friesen introduces a topic outside of the usual discussions of 